\title{
TERT promoter mutations in ocular melanoma distinguish between conjunctival and uveal tumours
}

\author{
K G Griewank ${ }^{*, 1}$, R Murali ${ }^{2,3}$, B Schilling ${ }^{1}$, S Scholz ${ }^{4}$, A Sucker ${ }^{1}$, M Song ${ }^{1}$, D Süsskind ${ }^{5}$, F Grabellus ${ }^{6}$, \\ L Zimmer $^{1}$, U Hillen ${ }^{1}$, K-P Steuhl ${ }^{4}$, D Schadendorf ${ }^{1}, \mathrm{H} \mathrm{Westekemper}^{4,8}$ and M Zeschnigk ${ }^{7,8}$ \\ ${ }^{1}$ Department of Dermatology, University Hospital, University Duisburg-Essen, Hufelandstrasse 55, Essen 45147, Germany; \\ ${ }^{2}$ Department of Pathology, Memorial Sloan-Kettering Cancer Center, New York, NY 10065, USA; ${ }^{3}$ Human Oncology and \\ Pathogenesis Program, Memorial Sloan-Kettering Cancer Center, New York, NY 10065, USA; ${ }^{4}$ Department of Ophthalmology, \\ University Hospital, University Duisburg-Essen, Hufelandstrasse 55, Essen 45147, Germany; ${ }^{5}$ Department of Ophthalmology, \\ University Hospital Tübingen, Tübingen 72076, Germany; ${ }^{6}$ Institute of Pathology and Neuropathology, University Hospital, \\ University Duisburg-Essen, Essen 45147, Germany and 'Institute of Human Genetics, University Hospital, University Duisburg- \\ Essen, Essen 45147, Germany
}

Background: Recently, activating mutations in the TERT promoter were identified in cutaneous melanoma. We tested a cohort of ocular melanoma samples for similar mutations.

Methods: The TERT promoter region was analysed by Sanger sequencing in 47 uveal (ciliary body or choroidal) melanomas and 38 conjunctival melanomas.

Results: Mutations of the TERT promoter were not identified in uveal melanomas, but were detected in 12 (32\%) conjunctival melanomas. Mutations had a UV signature and were identical to those found in cutaneous melanoma.

Conclusion: Mutations of TERT promoter with UV signatures are frequent in conjunctival melanomas and favour a pathogenetic kinship with cutaneous melanomas. Absence of these mutations in uveal melanomas emphasises their genetic distinction from cutaneous and conjunctival melanomas.

Cutaneous and ocular melanomas affect people worldwide and are associated with significant mortality (Singh et al, 2005; Siegel et al, 2012; Flaherty et al, 2012a). Currently, cure is achievable only in patients with localised disease. Once metastatic spread occurs, the prognosis is poor.

Cutaneous melanoma is characterised by activating driver mutations in genes such as BRAF (Davies et al, 2002), NRAS (Ball et al, 1994), and KIT (Curtin et al, 2006), and recurrent losses of specific tumour suppressors such as CDKN2A and PTEN (Curtin et al, 2005). In patients with certain genetic subsets of melanoma, recently introduced therapies such as BRAF inhibitors improve survival, even in advanced disease (Chapman et al, 2011; Hauschild et al, 2012; Flaherty et al, 2012b).

Uveal melanomas arise from the iris, ciliary body, or choroid of the eye. They comprise $\sim 90 \%$ of ocular melanomas and are genetically distinct from cutaneous melanoma. They are characterised by activating somatic mutations in either GNAQ or GNA11 (Van Raamsdonk et al, 2009, 2010). Based on gene expression profiles, uveal melanomas may be subdivided into two prognostic groups, termed class 1 (good prognosis) or class 2 (poor prognosis) (Tschentscher et al, 2003; Onken et al, 2004). Class 1 tumours frequently harbour SF3B1 mutations (Harbour

\footnotetext{
*Correspondence: Dr KG Griewank; E-mail: klaus.griewank@uk-essen.de

${ }^{8}$ These authors contributed equally.
} 
et al, 2013), whereas class 2 tumours typically show chromosomal monosomy 3 (Prescher et al, 1996), as well as inactivating BAP1 mutations (Harbour et al, 2010).

Conjunctival melanomas, unlike uveal melanomas, frequently harbour BRAF and NRAS mutations and copy number alterations reminiscent of cutaneous and mucosal melanoma (Gear et al, 2004; Spendlove et al, 2004; Goldenberg-Cohen et al, 2005; Lake et al, 2011; Griewank et al, 2013). Their clinical behaviour also differs from uveal melanoma and is similar to that of cutaneous melanomas (Zembowicz et al, 2010; Harooni et al, 2011; Shields et al, 2011).

Recently two studies showed that up to $71 \%$ of cutaneous melanomas harboured novel mutations in the promoter region of TERT, coding for the catalytic subunit of the telomerase holoenzyme (Horn et al, 2013; Huang et al, 2013). These mutations were shown to lead to increased TERT expression, most likely by creating ETS transcription-factor-binding sites (Horn et al, 2013; Huang et al, 2013). An additional study found TERT promoter mutations in a wide array of different human cancers, including bladder cancer, hepatocellular carcinoma, and different types of gliomas (Killela et al, 2013). They associated high frequencies of TERT promoter mutations, with tumours arising in tissues having low rates of self-renewal.

The frequency of TERT promoter mutations in ocular melanomas has not been analysed. Here, we investigated the presence of TERT promoter mutations in ocular melanomas including conjunctival and uveal melanomas.

\section{MATERIALS AND METHODS}

Sample selection. Ocular melanoma samples were obtained from patients treated in the Department of Ophthalmology for conjunctival or uveal (choroidal or ciliary body) melanoma, as well as from the tissue archives of the Departments of Ophthalmology, Pathology, and Dermatology, University Hospital Essen, Germany, and the Department of Ophthalmology, University Hospital Tübingen, Germany. The study was carried out in accordance with the guidelines set forth by the ethics committee of the University of Duisburg-Essen.

Clinical and pathological parameters. Clinical and pathological details were obtained from patient records. A review of pathological slides was also performed to confirm the conjunctival origin of tumours and to assess the following: site(s) of tumour involvement (primarily or secondarily); pathological stage; the presence of associated lesions such as conjunctival naevus and primary acquired melanosis; and pigmentation (presence of melanin pigment in the cytoplasm of tumour cells). Conjunctival naevus was defined as an acquired junctional or compound proliferation of benign melanocytes, usually in a nested pattern, in the conjunctiva. Primary acquired melanosis was defined clinically as flat, speckled brown lesions of the conjunctiva, and histologically as hyperpigmentation of conjunctival epithelium without melanocytic hyperplasia, or melanocytic hyperplasia in conjunctival epithelium with or without cytologic atypia.

DNA isolation. Ten-micrometre thick sections were cut from formalin-fixed, paraffin-embedded tumour tissues. The sections were deparaffinised and manually macrodissected according to the standard procedures. Genomic DNA was isolated using the QIAamp DNA Mini Kit (Qiagen, Hilden, Germany) according to the manufacturer's instructions. Samples of fresh frozen tissue were directly applied to the QIAamp DNA Mini Kit. Uveal melanoma sample DNA isolation and determination of chromosome 3 status by microsatellite analysis were performed as previously described (Thomas et al, 2012).
Table 1. Associations of TERT mutation status with clinical and pathological parameters in conjunctival melanoma

\begin{tabular}{|l|c|c|c|c|}
\hline Parameter & Level & $\begin{array}{c}\text { TERT } \\
\text { wild-type } \\
(\mathbf{n}=\mathbf{2 6})\end{array}$ & $\begin{array}{c}\text { TERT } \\
\text { mutant } \\
(\boldsymbol{n}=12)\end{array}$ & $\begin{array}{c}\boldsymbol{P} \text { - } \\
\text { value }\end{array}$ \\
\hline Median age (years) & Female & 15 & 6 & 1.00 \\
\hline Sex & Male & 10 & 5 & \\
\hline & & & 73.3 & $0.72^{\text {a }}$ \\
\hline Sites of & No & 11 & 8 & \\
involvement $^{\text {b }}$ & Yes & 12 & 2 & \\
Bulbar & No & 20 & 5 & 0.13 \\
& Yes & 2 & 4 & \\
Caruncle & No & 16 & 6 & 1.00 \\
Fornix & Yes & 6 & 2 & \\
Sclera & No & 23 & 9 & 0.51 \\
Palpebra & Yes & 1 & 1 & \\
& No & 19 & 6 & 0.32 \\
Multifocal & Yes & 3 & 3 & \\
& No & 16 & 4 & 0.14 \\
\hline Clinical stage & Yes & 7 & 6 & \\
\hline & la & 5 & 1 & 0.20 \\
\hline
\end{tabular}

\begin{tabular}{|c|c|c|c|c|}
\hline Clinical stage & $\begin{array}{l}\text { la } \\
\text { Ib } \\
\text { Ila } \\
\text { Ilb } \\
\text { Ilc } \\
\text { Ild } \\
\text { Illa } \\
\text { Illb }\end{array}$ & $\begin{array}{l}5 \\
7 \\
0 \\
6 \\
0 \\
1 \\
1 \\
3\end{array}$ & $\begin{array}{l}1 \\
1 \\
1 \\
2 \\
2 \\
0 \\
1 \\
2\end{array}$ & 0.20 \\
\hline Pathological stage & $\begin{array}{l}\text { I } \\
\text { la } \\
\text { Ib } \\
\text { Ic } \\
\text { Ila } \\
\text { Ilb } \\
\text { Ilc } \\
\text { III }\end{array}$ & $\begin{array}{l}1 \\
5 \\
3 \\
3 \\
4 \\
1 \\
1 \\
4\end{array}$ & $\begin{array}{l}0 \\
2 \\
0 \\
0 \\
1 \\
0 \\
4 \\
3\end{array}$ & 0.19 \\
\hline Associated lesion & $\begin{array}{c}\text { PAM } \\
\text { Naevus } \\
\text { De novo }\end{array}$ & $\begin{array}{r}15 \\
3 \\
5\end{array}$ & $\begin{array}{l}6 \\
1 \\
1\end{array}$ & 0.47 \\
\hline Cell type & $\begin{array}{c}\text { Mixed } \\
\text { Spindle } \\
\text { Epithelioid }\end{array}$ & $\begin{array}{r}13 \\
3 \\
3\end{array}$ & $\begin{array}{l}3 \\
3 \\
3\end{array}$ & 0.22 \\
\hline Pigmentation & $\begin{array}{l}\text { Yes } \\
\text { No }\end{array}$ & $\begin{array}{r}20 \\
1\end{array}$ & $\begin{array}{l}8 \\
1\end{array}$ & 0.52 \\
\hline NRAS mutation & $\begin{array}{l}\text { No } \\
\text { Yes }\end{array}$ & $\begin{array}{r}24 \\
2\end{array}$ & $\begin{array}{l}9 \\
3\end{array}$ & 0.30 \\
\hline BRAF mutation & $\begin{array}{l}\text { No } \\
\text { Yes }\end{array}$ & $\begin{array}{r}20 \\
6\end{array}$ & $\begin{array}{l}8 \\
4\end{array}$ & 0.69 \\
\hline Disease-free survival & $1.25(0.47-3.35)^{c}$ & $24^{d}$ & $18^{d}$ & $0.65^{e}$ \\
\hline Overall survival & $1.92(0.60-6.08)^{c}$ & $N R^{d}$ & $89^{d}$ & $0.27^{e}$ \\
\hline
\end{tabular}

Abbreviations: $N R=$ not reached; $P A M=$ primary acquired melanosis. $P$-values are derived from $\chi^{2}$ or Fisher's exact tests, as appropriate, unless otherwise specified. Clinical and pathological stage is according to the American Joint Committee on Cancer staging system for conjunctival melanoma, 7th edition. Note: The sum of the numbers of cases for individual parameters may not equal the total number of cases because data for some parameters was not available in all cases.

${ }^{a_{\text {Kruskal-Wallis test. }}}$

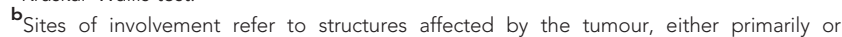
secondarily. Only tumours of conjunctival origin were included in the study.

${ }^{c}$ Hazard ratio (95\% confidence interval for hazard ratio).

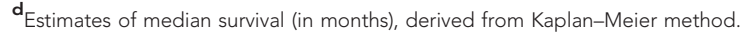

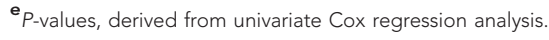


Direct (Sanger) sequencing. Nested PCR was performed to amplify BRAF exons 11 and 15 and NRAS exons 1 and 2, and sequenced as previously described (Houben et al, 2004). A 474-base pair region of the TERT promoter region was amplified using the following primers: hTERT_F $5^{\prime}$-ACGAACGTGGCCAGCGGCAG- $3^{\prime}$ and hTERT_R 5'-CTGGCGTCCCTGCACCCTGG-3'. For amplification of DNA from formalin-fixed material, primers hTERT_short_F $5^{\prime}$-CA GCGCTGCCTGAAACTC-3' and hTERT_short_R $5^{\prime}$-GTCCTGCCC CTTCACCTT-3', which amplify a 163 -bp fragment, were applied as previously described (Horn et al, 2013). After purification with the QIAquick PCR Purification Kit (Qiagen), PCR products were used as templates for sequencing. The sequencing chromatogram files were examined, and mutations were identified using Chromas software (version 2.01, University of Sussex, Brighton, UK).

\section{RESULTS}

Sample cohort. The study cohort consisted of 50 uveal melanoma samples (which included 22 tumours with chromosome 3 disomy, and 28 tumours with chromosome 3 monosomy) randomly selected from a cohort of 374 tumours described previously (Thomas et al, 2012), and 43 conjunctival melanoma samples. All the samples were primary or recurrent tumours. Available clinical data of conjunctival melanoma are listed in Table 1 and Supplementary Table 1.

TERT promoter mutation analysis. Sequence analysis failed in one and was ambiguous in two of the 50 uveal melanoma samples. In the remaining 47 samples (21 disomy 3, 26 monosomy 3), no TERT promoter mutations were identified. Sequence analysis was successful in 38 of the 43 conjunctival melanomas, and TERT promoter mutations were identified in 12 (32\%) tumours. The mutations were located at positions Chr.5:1295228C $>$ T $(n=2, \quad 5 \%), \quad$ Chr.5:1295242_43delinsTT $\quad(n=2,5 \%)$, and Chr.5:1295250C $>\mathrm{T}(n=8, \overline{21 \%})$, as shown in Figure 1. Mutations will be further annotated using the last three digits of their chromosome location as $228 \mathrm{C}>\mathrm{T}, 242 \mathrm{CC}>\mathrm{TT}$, and $250 \mathrm{C}>\mathrm{T}$ respectively. All identified TERT promoter mutations had a UV signature $(\mathrm{C}>\mathrm{T}$ and $\mathrm{CC}>\mathrm{TT}$ ) (Pleasance et al, 2010). In eight cases, matched constitutional DNA isolated from peripheral blood was sequenced. None of these samples harboured the TERT promoter mutations detected in the corresponding tumour DNA, verifying that the detected mutations were somatically acquired (Supplementary Figure 1).

$B R A F$ and NRAS mutations. Successful sequencing of $B R A F$ and NRAS was performed in the conjunctival melanoma samples. Ten of the thirty-eight tumours (26\%) harboured BRAF mutations: nine p.V600E (c.1799T > A) and one p.G469A (c.1406G > C). Four (40\%) BRAF-mutant samples had a concomitant TERT promoter mutation $(250 \mathrm{C}>\mathrm{T}, n=2$ and $228 \mathrm{C}>\mathrm{T}, n=2)$. Mutations of NRAS were present in five (13\%) conjunctival melanomas, including three p.Q61R (c.182A $>\mathrm{G})$ and two p.Q61K (c.181C > A) mutations. Three (60\%) NRAS-mutant samples had concomitant TERT promoter mutations $(250 \mathrm{C}>\mathrm{T}, n=3)$.

Associations of clinical and pathological parameters with TERT mutation status in conjunctival melanoma. An analysis with the available clinicopathological data was performed. Median followup duration was 39.2 months (3.2-171 months). Five (13\%) patients were lost to follow-up. No statistically significant associations of TERT promoter mutation status with clinical and pathological parameters (age, sex, site of tumour involvement, clinical stage, pathological stage, associated lesion, and pigmentation) or with disease-free survival or overall survival were found (Table 1).

\section{DISCUSSION}

Mutations of the TERT promoter were quite frequent (32\%) in conjunctival melanoma, but were not seen in uveal melanomas. The mutations identified in conjunctival melanoma are identical to those described in cutaneous melanoma (Horn et al, 2013; Huang et al, 2013). They were found at the same hotspots and were mutually exclusive of each other. Additionally, all mutations showed a UV signature, consisting of $\mathrm{C}>\mathrm{T}$ or $\mathrm{CC}>\mathrm{TT}$ nucleotide changes (Pleasance et al, 2010). The frequencies of TERT promoter mutations reported in cutaneous melanoma vary significantly, probably in part due to varying sample selection (type of melanomas, primary or metastatic samples, and so on). The mutation frequency of $33 \%$ reported by Horn et al (2013) in primary cutaneous melanomas is very similar to the mutation rate of $32 \%$ detected in our cohort of

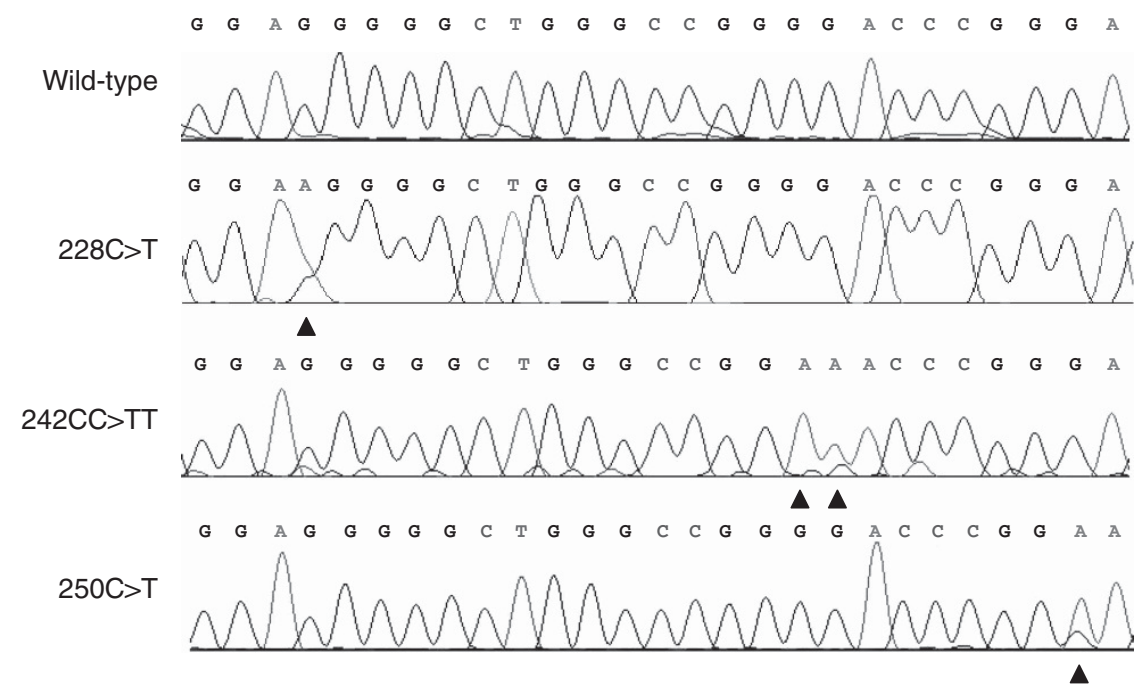

Figure 1. Mutations identified in the TERT promoter. Representative electropherograms showing the wild-type sequence from a uveal melanoma sample (on top) and the mutations identified in three conjunctival melanoma samples -Chr.5:1295228C > T, Chr.5:1295242_43delinsTT, and Chr.5:1295250C > T (hg19 assembly). Mutations in the figure are labeled using the last three digits of the first nucleotide mutated (underlined). The black arrowheads indicate the respective nucleotide changes. 
conjunctival melanoma samples. This finding provides further evidence for a pathogenetic link between cutaneous and conjunctival melanomas. Further support for such a link derives from the frequency of BRAF and NRAS mutations, and similarity of clinical behaviour between these melanoma types.

In our cohort of 38 conjunctival melanomas, there were no significant associations between TERT promoter mutation status and clinicopathological parameters. Future studies with larger tumour cohorts will be required to validate these findings.

Our results underline the distinct pathogenesis of uveal melanoma compared with other forms of melanoma. Mutations of the TERT promoter join the list of genetic events such as mutations in BRAF or NRAS and losses of PTEN or CDKN2A, which are very common in cutaneous melanoma but are virtually never seen in uveal melanoma. Considering that correspondingly, almost all genetic events identified in uveal melanoma, such as mutations in GNAQ (Van Raamsdonk et al, 2009), GNA11 (Van Raamsdonk et al, 2010), BAP1 (Harbour et al, 2010), and SF3B1 (Harbour et al, 2013), are rarely seen in cutaneous or mucosal melanoma; uveal melanomas potentially will be found to harbour their own unique set of recurrent mutations in regulatory DNA regions (that is, promoters, enhancers, and so on).

Killela et al (2013) found high frequencies ( $>15 \%)$ of TERT promoter mutations in tumours arising from tissues with low selfrenewal capability. Our results suggest that this phenomenon may apply to conjunctival melanoma, as well as cutaneous melanoma. In certain cancers, Killela et al (2013) reported alternative lengthening of telomeres (ALT) with inactivating mutations in $A T R X$ and DAXX as a mechanism for telomere maintenance in TERT promoter mutation-negative samples. Alternative lengthening of telomeres has generally not been reported to be relevant in melanoma. Additionally, larger whole-exome sequencing studies both for cutaneous melanoma ((Hodis et al, 2012; Krauthammer et al, 2012), $n>250)$ and uveal melanoma ((Harbour et al, 2013) and our own unpublished data, $n=40)$ did not find recurrent mutations in ATRX or DAXX. This argues against a relevant role for ALT in ocular melanoma.

The role of UV-mediated tumourigenesis in ocular melanomas is yet to be resolved (Pane and Hirst, 2000; Guenel et al, 2001; Singh et al, 2004). The UV signature in the mutations identified in the TERT promoter of conjunctival melanomas suggests a potential role for UV-induced genetic alterations in the pathogenesis of these tumours. Whether UV radiation contributes to the development of uveal melanomas is yet to be determined.

In summary, the distribution of TERT promoter mutations in ocular melanoma provides further evidence that ocular melanomas comprise genetically distinct tumour groups. The presence of TERT promoter mutations with UV signatures in conjunctival melanomas supports an UV-induced pathogenesis and a pathogenetic kinship with cutaneous melanomas. Absence of these mutations in uveal melanomas emphasises their genetic distinction from cutaneous and conjunctival melanomas.

\section{ACKNOWLEDGEMENTS}

We would like to thank Iris Moll, Marion Schwamborn, and Nicola Bielefeld for their excellent technical support. Bastian Schilling has received travel support from BMS. The research was supported by a grant from the Werner-Jackstädt-Stiftung.

\section{CONFLICT OF INTEREST}

Dirk Schadendorf is on the advisory board and has received honararia from Roche, Genetech, Novartis, Amgen, GSK, BMS,
Boehringer Ingelheim, and Merck. Lisa Zimmer has received honoraria from Roche, Bristol-Meyers Squibb, and Amgen, and travel support from Merck Sharp \& Dohme and Bristol-Meyers Squibb. Bastian Schilling has received travel support from BMS. The remaining authors declare no conflict of interest.

\section{DISCLAIMER}

The funders had no role in study design, data collection and analysis, decision to publish, or preparation of the manuscript.

\section{REFERENCES}

Ball NJ, Yohn JJ, Morelli JG, Norris DA, Golitz LE, Hoeffler JP (1994) Ras mutations in human melanoma: a marker of malignant progression. J Invest Dermatol 102(3): 285-290.

Chapman PB, Hauschild A, Robert C, Haanen JB, Ascierto P, Larkin J, Dummer R, Garbe C, Testori A, Maio M, Hogg D, Lorigan P, Lebbe C, Jouary T, Schadendorf D, Ribas A, O'Day SJ, Sosman JA, Kirkwood JM, Eggermont AM, Dreno B, Nolop K, Li J, Nelson B, Hou J, Lee RJ, Flaherty KT, McArthur GA (2011) Improved survival with vemurafenib in melanoma with BRAF V600E mutation. $N$ Engl J Med 364(26): 2507-2516.

Curtin JA, Busam K, Pinkel D, Bastian BC (2006) Somatic activation of KIT in distinct subtypes of melanoma. J Clin Oncol 24(26): 4340-4346.

Curtin JA, Fridlyand J, Kageshita T, Patel HN, Busam KJ, Kutzner H, Cho KH, Aiba S, Brocker EB, LeBoit PE, Pinkel D, Bastian BC (2005) Distinct sets of genetic alterations in melanoma. $N$ Engl J Med 353(20): 2135-2147.

Davies H, Bignell GR, Cox C, Stephens P, Edkins S, Clegg S, Teague J, Woffendin H, Garnett MJ, Bottomley W, Davis N, Dicks E, Ewing R, Floyd Y, Gray K, Hall S, Hawes R, Hughes J, Kosmidou V, Menzies A, Mould C, Parker A, Stevens C, Watt S, Hooper S, Wilson R, Jayatilake H, Gusterson BA, Cooper C, Shipley J, Hargrave D, Pritchard-Jones K, Maitland N, Chenevix-Trench G, Riggins GJ, Bigner DD, Palmieri G, Cossu A, Flanagan A, Nicholson A, Ho JW, Leung SY, Yuen ST, Weber BL, Seigler HF, Darrow TL, Paterson H, Marais R, Marshall CJ, Wooster R, Stratton MR, Futreal PA (2002) Mutations of the BRAF gene in human cancer. Nature 417(6892): 949-954.

Flaherty KT, Hodi FS, Fisher DE (2012a) From genes to drugs: targeted strategies for melanoma. Nat Rev Cancer 12(5): 349-361.

Flaherty KT, Infante JR, Daud A, Gonzalez R, Kefford RF, Sosman J, Hamid O, Schuchter L, Cebon J, Ibrahim N, Kudchadkar R, Burris 3rd HA, Falchook G, Algazi A, Lewis K, Long GV, Puzanov I, Lebowitz P, Singh A, Little S, Sun P, Allred A, Ouellet D, Kim KB, Patel K, Weber J (2012b) Combined BRAF and MEK inhibition in melanoma with BRAF V600 mutations. N Engl J Med 367(18): 1694-1703.

Gear H, Williams H, Kemp EG, Roberts F (2004) BRAF mutations in conjunctival melanoma. Investig Ophthalmol Vis Sci 45(8): 2484-2488.

Goldenberg-Cohen N, Cohen Y, Rosenbaum E, Herscovici Z, Chowers I, Weinberger D, Pe'er J, Sidransky D (2005) T1799A BRAF mutations in conjunctival melanocytic lesions. Investig Ophthalmol Vis Sci 46(9): 3027-3030.

Griewank K, Westekemper H, Murali R, Mach M, Schilling B, Wiesner T, Schimming T, Livingstone E, Sucker A, Grabellus F, Metz C, Susskind D, Hillen U, Speicher MR, Woodman SE, Steuhl KP, Schadendorf D (2013) Conjunctival melanomas harbor BRAF and NRAS mutations and copy number changes similar to cutaneous and mucosal melanomas. Clin Cancer Res, in press; doi: 10.1158/1078-0432.CCR-13-0163.

Guenel P, Laforest L, Cyr D, Fevotte J, Sabroe S, Dufour C, Lutz JM, Lynge E (2001) Occupational risk factors, ultraviolet radiation, and ocular melanoma: a case-control study in France. Cancer Causes Control 12(5): 451-459.

Harbour JW, Onken MD, Roberson ED, Duan S, Cao L, Worley LA, Council ML, Matatall KA, Helms C, Bowcock AM (2010) Frequent mutation of BAP1 in metastasizing uveal melanomas. Science 330(6009): $1410-1413$

Harbour JW, Roberson ED, Anbunathan H, Onken MD, Worley LA, Bowcock AM (2013) Recurrent mutations at codon 625 of the splicing factor SF3B1 in uveal melanoma. Nat Genet 45(2): 133-135. 
Harooni H, Schoenfield LR, Singh AD (2011) Current appraisal of conjunctival melanocytic tumors: classification and treatment. Future Oncol 7(3): 435-446.

Hauschild A, Grob JJ, Demidov LV, Jouary T, Gutzmer R, Millward M, Rutkowski P, Blank CU, Miller Jr. WH, Kaempgen E, Martin-Algarra S, Karaszewska B, Mauch C, Chiarion-Sileni V, Martin AM, Swann S, Haney P, Mirakhur B, Guckert ME, Goodman V, Chapman PB (2012) Dabrafenib in BRAF-mutated metastatic melanoma: a multicentre, openlabel, phase 3 randomised controlled trial. Lancet 380(9839): 358-365.

Hodis E, Watson IR, Kryukov GV, Arold ST, Imielinski M, Theurillat JP, Nickerson E, Auclair D, Li L, Place C, Dicara D, Ramos AH, Lawrence MS, Cibulskis K, Sivachenko A, Voet D, Saksena G, Stransky N, Onofrio RC, Winckler W, Ardlie K, Wagle N, Wargo J, Chong K, Morton DL, Stemke-Hale K, Chen G, Noble M, Meyerson M, Ladbury JE, Davies MA, Gershenwald JE, Wagner SN, Hoon DS, Schadendorf D, Lander ES, Gabriel SB, Getz G, Garraway LA, Chin L (2012) A landscape of driver mutations in melanoma. Cell 150(2): 251-263.

Horn S, Figl A, Rachakonda PS, Fischer C, Sucker A, Gast A, Kadel S, Moll I, Nagore E, Hemminki K, Schadendorf D, Kumar R (2013) TERT promoter mutations in familial and sporadic melanoma. Science 339(6122): 959-961.

Houben R, Becker JC, Kappel A, Terheyden P, Brocker EB, Goetz R, Rapp UR (2004) Constitutive activation of the Ras-Raf signaling pathway in metastatic melanoma is associated with poor prognosis. J Carcinog 3(1): 6 .

Huang FW, Hodis E, Xu MJ, Kryukov GV, Chin L, Garraway LA (2013) Highly recurrent TERT promoter mutations in human melanoma. Science 339(6122): 957-959.

Killela PJ, Reitman ZJ, Jiao Y, Bettegowda C, Agrawal N, Diaz Jr LA, Friedman AH, Friedman H, Gallia GL, Giovanella BC, Grollman AP, He TC, He Y, Hruban RH, Jallo GI, Mandahl N, Meeker AK, Mertens F, Netto GJ, Rasheed BA, Riggins GJ, Rosenquist TA, Schiffman M, Shih IM, Theodorescu D, Torbenson MS, Velculescu VE, Wang TL, Wentzensen N, Wood LD, Zhang M, McLendon RE, Bigner DD, Kinzler KW, Vogelstein B, Papadopoulos N, Yan H (2013) TERT promoter mutations occur frequently in gliomas and a subset of tumors derived from cells with low rates of self-renewal. Proc Natl Acad Sci USA 110(15): 6021-6026.

Krauthammer M, Kong Y, Ha BH, Evans P, Bacchiocchi A, McCusker JP, Cheng E, Davis MJ, Goh G, Choi M, Ariyan S, Narayan D,

Dutton-Regester K, Capatana A, Holman EC, Bosenberg M, Sznol M, Kluger HM, Brash DE, Stern DF, Materin MA, Lo RS, Mane S, Ma S, Kidd KK, Hayward NK, Lifton RP, Schlessinger J, Boggon TJ, Halaban R (2012) Exome sequencing identifies recurrent somatic RAC1 mutations in melanoma. Nat Genet 44(9): 1006-1014.

Lake SL, Jmor F, Dopierala J, Taktak AF, Coupland SE, Damato BE (2011) Multiplex ligation-dependent probe amplification of conjunctival melanoma reveals common BRAF V600E gene mutation and gene copy number changes. Investig Ophthalmol Vis Sci 52(8): 5598-5604.

Onken MD, Worley LA, Ehlers JP, Harbour JW (2004) Gene expression profiling in uveal melanoma reveals two molecular classes and predicts metastatic death. Cancer Res 64(20): 7205-7209.
Pane AR, Hirst LW (2000) Ultraviolet light exposure as a risk factor for ocular melanoma in Queensland, Australia. Ophthalmic Epidemiol 7(3): 159-167.

Pleasance ED, Cheetham RK, Stephens PJ, McBride DJ, Humphray SJ, Greenman CD, Varela I, Lin ML, Ordonez GR, Bignell GR, Ye K, Alipaz J, Bauer MJ, Beare D, Butler A, Carter RJ, Chen L, Cox AJ, Edkins S, Kokko-Gonzales PI, Gormley NA, Grocock RJ, Haudenschild CD, Hims MM, James T, Jia M, Kingsbury Z, Leroy C, Marshall J, Menzies A, Mudie LJ, Ning Z, Royce T, Schulz-Trieglaff OB, Spiridou A, Stebbings LA, Szajkowski L, Teague J, Williamson D, Chin L, Ross MT, Campbell PJ, Bentley DR, Futreal PA, Stratton MR (2010) A comprehensive catalogue of somatic mutations from a human cancer genome. Nature 463(7278): 191-196.

Prescher G, Bornfeld N, Hirche H, Horsthemke B, Jöckel KH, Becher R (1996) Prognostic implications of monosomy 3 in uveal melanoma. Lancet 347(9010): 1222-1225.

Shields CL, Markowitz JS, Belinsky I, Schwartzstein H, George NS, Lally SE, Mashayekhi A, Shields JA (2011) Conjunctival melanoma: outcomes based on tumor origin in 382 consecutive cases. Ophthalmology 118(2): 389-95 e1-2.

Siegel R, Naishadham D, Jemal A (2012) Cancer statistics, 2012. Cancer J Clin 62(1): 10-29.

Singh AD, Bergman L, Seregard S (2005) Uveal melanoma: epidemiologic aspects. Ophthalmol Clin North Am 18(1): 75-84viii.

Singh AD, Rennie IG, Seregard S, Giblin M, McKenzie J (2004) Sunlight exposure and pathogenesis of uveal melanoma. Surv Ophthalmol 49(4): $419-428$.

Spendlove HE, Damato BE, Humphreys J, Barker KT, Hiscott PS, Houlston RS (2004) BRAF mutations are detectable in conjunctival but not uveal melanomas. Melanoma Res 14(6): 449-452.

Thomas S, Putter C, Weber S, Bornfeld N, Lohmann DR, Zeschnigk M (2012) Prognostic significance of chromosome 3 alterations determined by microsatellite analysis in uveal melanoma: a long-term follow-up study. $\mathrm{Br}$ $J$ Cancer 106(6): 1171-1176.

Tschentscher F, Hüsing J, Hölter T, Kruse E, Dresen IG, Jöckel KH, Anastassiou G, Schilling H, Bornfeld N, Horsthemke B, Lohmann DR, Zeschnigk M (2003) Tumor classification based on gene expression profiling shows that uveal melanomas with and without monosomy 3 represent two distinct entities. Cancer Res 63(10): 2578-2584.

Van Raamsdonk CD, Bezrookove V, Green G, Bauer J, Gaugler L, O’Brien JM, Simpson EM, Barsh GS, Bastian BC (2009) Frequent somatic mutations of GNAQ in uveal melanoma and blue naevi. Nature 457(7229): 599-602.

Van Raamsdonk CD, Griewank KG, Crosby MB, Garrido MC, Vemula S, Wiesner T, Obenauf AC, Wackernagel W, Green G, Bouvier N, Sozen MM, Baimukanova G, Roy R, Heguy A, Dolgalev I, Khanin R, Busam K, Speicher MR, O'Brien J, Bastian BC (2010) Mutations in GNA11 in uveal melanoma. N Engl J Med 363(23): 2191-2199.

Zembowicz A, Mandal RV, Choopong P (2010) Melanocytic lesions of the conjunctiva. Arch Pathol Lab Med 134(12): 1785-1792.

Supplementary Information accompanies this paper on British Journal of Cancer website (http://www.nature.com/bjc) 